\title{
DIET PREFERENCES AND REPRODUCTION OF TRANSLOCATED BARN OWL, Tyto alba javanica IN CAPTIVITY
}

\author{
CIK MOHD RIZUAN, Z A*; NOOR HAFIDZI, M N*; NOOR HISHAM, $\mathrm{H}^{\star}$ and HASBER SALIM ${ }^{\star}$
}

\begin{abstract}
Five non-paired-translocated wild caught barn owl (Tyto alba javanica) transferred from Jerantut, Pahang in Peninsular to Lahad Datu in Sabah, Malaysia were tested for diet preference by size, and species and fecundity in captivity. Testing was done in flight cages where owls were free to select from a combination of three local rodent species distinguished into two size categories; large and small. Jacobs' index confirmed that smaller rats were taken in greater numbers and took the shortest number of days to $100 \%$ consumption at Day 5 than larger ones. Preference for body parts consumed varied according to diet size and species. In the same period as the prey preference study, two females reproduced twice ranging from intervals of 44 to 63 days with an average clutch size of 6.8 eggs. Hatching rates ranged from $0 \%$ to $83 \%$ and fledging rates ranged from $0 \%$ to $75 \%$. These results may have practical importance in the propagation of barn owls in their new environment as they will be exposed to different prey in terms of species and size range.
\end{abstract}

Keywords: barn owl, diet preference, rats.

Date received: 27 December 2016; Sent for revision: 20 March 2017; Received in final form: 9 July 2017; Accepted: 3 August 2017.

\section{INTRODUCTION}

Understanding the way predators respond to prey size can provide insights into the ability of species to establish in their new environment. Predators must do so with some efficiency so as not to expand net energy. Size of prey is an important factor in measuring efficiency in food consumption (Marti and Hogue, 1979). Many animal species changed their feeding behaviour to allow them to survive well and adapt in their new habitat (Cavalli et al., 2014). In natural habitat, prey choices of barn owls varied widely from shrews, birds, voles and mice,

* Crop Protection \& Beneficial Microbes Division,

Felda Global Ventures Research and Development Sdn Bhd,

Pusat Penyelidikan Pertanian Tun Razak,

26400 Bandar Jengka, Pahang, Malaysia.

E-mail: cikwan.za@gmail.com

** Department Plant Protection, Faculty of Agriculture, Universiti Putra Malaysia, 43400 UPM Serdang, Selangor, Malaysia.

\# School of Biological Sciences, Universiti Sains Malaysia, 11800 Minden, Pulau Pinang, Malaysia. bats and insects (Flikweert et al., 2007; Muhammad et al., 2007; Taylor, 2009); primarily exclusive on rats (Hafidzi et al., 2003; Trejo and Lambertucci, 2007; Bontzorlos et al., 2009) and typically are specialist on small mammals (Taylor, 1994; Marti, 2010; Puan et al., 2011).

Numerous predation studies have been carried out throughout the world, involving many owl species, e.g. screech owls: [barred eagle owl (Bubo sumatranus; Foley et al., 2013), Otus asio; Marti and Hogue, 1979], burrowing owls (Athene cunicularia; Littles et al., 2007, Cavalli et al., 2014), spotted owlets (Athene brama; Pande et al., 2007), snowy owls (Bubo scandiaca; Detienne et al., 2008), tawny owls (Strix aluco; Sunde et al., 2007), ural owls (Strix uralensis; Karell et al., 2010), magellanic horned owls (Bubo magellanicus; Trejo and Guthmann, 2003) and longeared owl (Asio otus: Khaleghizadeh et al., 2009). Barn owl diet also varied depending on changes in prey density (Puan et al., 2011) and habitat or microhabitat type (Colvin, 1984; Trejo and Guthmann, 2003). Some researchers have established that barn owls made 
their feeding choices based on energetics and size of prey (Smal, 1990; Gubanyi et al., 1992; Ille, 1991), i.e. either small (Heywood and Pavey, 2002; Tores et al., 2005), medium (Vanitha and Kanakasabai, 2009) or large (Castro and Jaksic, 1995).

Normally, barn owls start nesting at the age of eight months to one year and produced one brood per year (Bunn et al., 1982; Lenton, 1984; Colvin, 1984; Marti, 1992; 1994). Barn owls have great variability in clutch sizes ranging from 2-18 eggs (average clutch size of 6.6) lay at intervals of two to three days although longer gaps are sometimes encountered (Lenton, 1984; Taylor, 1994). Previous studies showed about $70 \%-85 \%$ of barn owl eggs hatched successfully (Taylor, 1994), $84.42 \%$ in an oil palm plantation (Naim et al,. 2011) and $79.25 \%$ to $85.72 \%$ in a rice field (Hafidzi et al., 2007). The instability of habitat quality was associated with reduced survivorship of individual barn owl but the effect is unlikely, given the overall fecundity of the population (Martin et al., 2010). Bunn et al. (1982) described that a young owl fledged at eight or nine weeks starts to hunt and continue to roost nearest to the nest. The fledgling success in oil palm plantations has been recorded at $81.2 \%$ (Lenton, 1984); at 77.9\%78.04\% (Naim et al., 2011; Hasber et al., 2014) and at $26.57 \%$ to $39.84 \%$ in oil palm plantation under rodenticide application (Hasber et al., 2014).

There is a dearth of publications on prey selection and reproductive success of owl species in South-east Asia and Malaysia particularly in captive conditions. Moreover, since the barn owl is an introduced species in Borneo Malaysia, no information as yet exists on various aspects of predation of barn owls on local prey species particularly in the east coast of Sabah; the fecundity or reproductive rate; and their response to the prey composition which is a departure from their place of origin in Peninsular Malaysia. In this study, the translocated barn owls were acclimatised in an aviary before being released in the field (oil palm plantation). The aim of this study was to investigate: (1) whether there was evidence of differential feeding by barn owls in terms of prey size and species under captive conditions; and (2) the fecundity of translocated barn owls in captivity.

\section{MATERIALS AND METHODS}

\section{Study Site}

The study was conducted over a 10-month period in a specially designed aviary with dimensions of $15.24 \mathrm{~m}$ length $\times 4.2 \mathrm{~m}$ width $\times 4.2$ $\mathrm{m}$ high; partitioned into five compartments (3.1 $\mathrm{m}$ length $\times 4.2 \mathrm{~m}$ width $\times 4.2 \mathrm{~m}$ high) situated in a mature oil palm at Felda Agriculture Services Sdn. Bhd, (FASSB) oil palm plantation scheme in Sahabat $\left(5^{\circ} 05^{\prime} \mathrm{N}, 119^{\circ} 03^{\prime} \mathrm{E}\right)$, Lahad Datu, in the east coast of Sabah, Malaysia. A single unit of fibre glass nest box $(0.7 \mathrm{~m}$ length $\times 0.3 \mathrm{~m}$ width $\times 0.3 \mathrm{~m}$ high $)$ and perches were installed in each compartment. A feeding arena $(1.8 \mathrm{~m}$ length $\times 41.2 \mathrm{~m}$ width $\times 1.2$ $\mathrm{m}$ high) was provided for ad libitum feeding of the barn owls with rats.

\section{Study Animals}

Five non-pairing barn owls were obtained from Jerantut, Pahang, east Peninsular Malaysia. They were brought by air cargo $(2.5 \mathrm{hr})$ to Tawau airport, Sabah and transferred by land $(4.5 \mathrm{hr})$ to the FGV Sahabat region, Lahad Datu. The owls were paired up in individual partitions in the aviary for conditioning. Five fibreglass nest boxes and roosting perches were furnished in the aviary for a resemblance of its natural habitat to encourage breeding. Food was provided by releasing live rodenticide-free rats in five feeding arenas. The rats were sustained with water and ripe oil palm fruits, twice a week.

\section{Treatment and Data Collection}

\section{Diet analysis.}

\section{a. Prey preferences}

Three rat species each with different size categories i.e. Rattus rattus diardii [size; large (L,151-285 g)], 60\%: medium (M, 101-150 g), 30\%; small (S, 50-100 g), $10 \%$, R. exulans [size; M(51-80 g)], 60\%: S [(20$50 \mathrm{~g}), 40 \%$ ] and Maxomys whiteheadi [size; M(51-80 g)], $60 \%: S(20-50 \mathrm{~g}), 40 \%$ ] in the range of 20 to 35 rats were offered to the 10 caged T. alba on a weekly basis; distributed in three separate feeding arenas. The three species of rats fed in Sabah were not found in Jerantut, Pahang. Each rat species was pooled, size categories based on absolute weight and their tail was marked accordingly around the tail with tapes of different colours. The carcasses and regurgitated pellets were sampled weekly and identified to size and species based on the colour of the tape, or otherwise identified based on body size, hind foot measurements, tail lengths, or bi-coloured tails in the case of $M$. whiteheadi (Vanitha and Kanakasabai, 2009). Regurgitated pellets were pooled and only complete pellets (holding entire body) were sorted and analysed using the standard techniques (Payne and Francis, 1985; Francis, 2008; Marti, 2009). The study was repeated for 14 weekly periods.

\section{b. Day consumption}

The method for this study followed the prey preferences study as above. However, the number of prey consumed were recorded on alternate days, 
i.e. at Day $1,3,5$, and 7 . The feeding was repeated for 10 weekly periods.

Breeding and reproductive rate. Another aspect investigated was the relationship between prey preference and the reproductive rates of $T$. alba javanica. The captive owls have formed breeding pairs after being kept for a period of time in the aviary. Since breeding pairs were identified with their corresponding clutch, they were isolated from one another by partitions measuring $3.1 \mathrm{~m}$ length $\mathrm{x}$ $4.2 \mathrm{~m}$ width $\times 4.2 \mathrm{~m}$ high, within the aviary. Three breeding pairs were followed until all the owlets turn to fledglings within three months. The five partitioned aviaries can be left open occasionally to provide a larger flying space, thus avoiding collisions against the wire strengthened walls. The owls were served with rats weekly with an average daily of rat-owl ratio af 2:1.

Prey selected and consumed was monitored at Day 1, 3 and 7 (a period from the first eggs laid until the fledged stage). As hunting and feeding normally occurs at night, and to lessen disturbance to the brooding activity, video recording was opted for later observations and analysis. A scouting camera with 8 megapixels and IR image detection [Super Scouter brand; Model DTC-560K (Time lapse camera)] recorded at intervals of $1 \mathrm{~min}$ up to three nights weekly depending on battery life. Three out of five juveniles (two from parent encoded JJ01 and one from HT01) were isolated from their respective parents to the new partition aviary for training and observation. At week four, owlets were fed with pellets of fresh rat meat until they were able to hunt the preys offered in the feeding arena. Three rat species with different size categories (three species represented by one rat from each size categories) were offered weekly to examine response of fledglings toward preys.

\section{Data Analysis}

The Jacobs' prey-selectivity index (Jacob, 1974) was used in order to estimate prey selectivity for rodents in the diet, as $\mathrm{D}=\mathrm{r}-\mathrm{p} /(\mathrm{r}+\mathrm{p}-2 \mathrm{rp})$, where $r$ is the proportion of a particular species and $p$ is the proportion of that prey in the population. Values of Jacobs' index range from - 1 (complete avoidance) to +1 (exclusive selection). Next, to calculate the mean for different species, the data of similar-species categories and size categories from all the feeding arenas was pooled during each weekly feeding period. The daily predation was compared using non-parametric equivalent of the one-way analysis of variance (ANOVA), the Kruskal-Wallis test and additionally with pairwise comparison $(\mathrm{P}<0.05)$ with Mann-Whitney $U$ test. The differences in predation in rat species and weight classes were assessed using non-parametric equivalent of the two-way ANOVA Scheirer-Ray-Hare test and additional pairwise comparison $(\mathrm{P}<0.05)$ with Mann-Whitney U test. Analysis was completed in IBM SPSS Statistics version 20, IBM corporation, Armonk, New York (Calvin, 2003). Appropriate variance structures were selected and a significance level of $P=0.05$ was used throughout. The variables of prey size and weight were reduced as much as possible.

\section{RESULTS AND DISCUSSION}

\section{Diet Preferences}

Rattus. $r$. diardii was the least preferred prey as the relative preference index value was the lowest compared to the two others (23.70), substantiated by Jacobs' preference index (Table 1). The two smallest species were completely $(100 \%)$ consumed as early as at Day five compared to R. r. diardii $(74.8 \%)$ (Table 2). Kruskal-Wallis $\mathrm{H}$ test showed that there was a significant difference in the daily predation of the different rat species by the barn owls, $\chi^{2}(2)$ $=7.776, P=0.020$, with a mean rank predation of $21.78,34.83$ and 39.90 for $R$. r. diardii, R. exulans and M. whiteheadi respectively (Table 2).

Barn owl's prey parts selection varied according to the prey size class. When all species were offered simultaneously (multi choice feeding), the owls preferred the small size followed by the medium and large size categories. In the present study, the owls preferred the small size prey rather than species. This is particularly true for $R$. exulans and M. whiteheadi. Thus, the owls prefer smaller size prey rather than the larger prey species, due to their relatively higher energy return. Furthermore, the barn owls were more likely to swallow the entire prey when the prey size was small across the species offered. Nutritive value of the prey, as well as the time consumed and energy cost of searching and subduing the prey all play a crucial role in predator prey selection (Griffith, 1980). The size of prey is an important factor in efficient foraging strategy. However in the east coast of Sabah, the smaller prey species was only found in new replanting or young palm areas while larger prey species were more dominant in mature palms (Cik Mohd Rizuan and Noor Hisham, 2015). This is an anticipated challenge for the owls since they will eventually be released in mature oil palm plantations.

For a large rat species (R. r. diardii), there were statistically significant difference in mean weight categories $(\mathrm{g})$ between small, medium and large prey $(P=0.007)$ and between proportion of prey consumed $(P<0.05)$. Owls were capable of swallowing entire prey for small and medium size prey but not for large sized prey of $R$. r. diardi $(P<0.05)$ (Table 3$)$. In addition, within these weight classes, the owls fed 
TABLE 1. RELATIVE PREFERENCE OF DIFFERENT PREY SPECIES BY THE BARN OWL

\begin{tabular}{lccc}
\hline Prey species & \multicolumn{3}{c}{$\%$, Means preferences } \\
\cline { 2 - 4 } & Absolute & Relative & Jacob's index, D \\
\hline Rattus r. diardii & 74.6 & 23.70 & 0.662 \\
Rattus exulans & 97.8 & 32.59 & 0.978 \\
Maxomys whiteheadi & 91.5 & 32.10 & 0.962 \\
& & & \\
\hline
\end{tabular}

mostly on partially and decapitated or dismembered prey constituting $34.75 \%$ and $45.28 \%$ of the medium and large sized prey item respectively (Table 3 ). But with the large prey size (more than $100 \mathrm{~g}$ ), owls need to decapitate the prey and expand more energy and it was more apparent in the large weight class of $R$. $r$. diardii. The proportions of prey consumed were highest for entire prey for all the species and size categories except for medium and large $R$. r. diardii (Tables 3 and 4). For smaller species (R. exulans and $M$. whiteheadi), there was no significant difference in mean size categories $(\mathrm{g})$ between small and large $(P$ $=0.73$ and $P=0.86$ ), however there was a significant difference between proportions of prey consumed $(\mathrm{P}<0.05)$ (Table 4).

Owls mostly preferred consuming the entire body of small sized prey $(P<0.05)$. Consuming head alone was the second highest partial prey category for medium and large class of $R$. r. diardi. It is presumed that the head provides sufficient meal for energy. In addition, biochemical analysis has confirmed that protein, carbohydrate and lipid levels were higher in the brain tissues of rodents and this explains why barn owl was likely consumed head alone, either front half of the body or the entire prey particularly of small rodent species (Vanitha and Kanakasabai, 2009). The barn owls have been thriving well and managed to adapt to the new environment within the acclimatisation period without much trouble. This study indicates that translocated barn owls were capable of adapting to a new prey species in its new environment (larger prey than their place of origin) with preference to smaller species and size categories. This is in agreement with Gliwitz (2008) who found a high significant relationship between avian predator size and both average and maximum prey size, but no such correlation was found for the minimum body size of prey. On the contrary, Puan et al. (2011) found no clear evidence of prey selection by barn owls in relation to size or sex of prey in either breeding or non-breeding seasons.

\section{Reproductive Success of Barn Owls in Captivity}

Pre-breeding behaviour. Two out of five pairs of birds initiated breeding in the aviary constructed for their acclimatisation. There was only one case recorded of in-breeding in the first generation. The first sign

TABLE 2. MULTI-CHOICE EXPERIMENTS ON PREY SPECIES PREFERENCE BY THE BARN OWL AGAINST DAYS OFFERED

\begin{tabular}{lcccc}
\hline Prey species & & \multicolumn{3}{c}{ Day \& \%, cumulative consumed } \\
\cline { 3 - 5 } & $\begin{array}{c}\text { Mean weight } \\
\text { class }(\mathbf{g}) \pm \text { SE }\end{array}$ & $\mathbf{1}$ & $\mathbf{3}$ & $\mathbf{5}$ \\
\hline Rattus r. diardii & $140.72 \pm 7.81$ & $10.5 \pm 1.4 \mathrm{a}$ & $45.9 \pm 4.6 \mathrm{a}$ & $74.8 \pm 2.0 \mathrm{a}$ \\
Rattus exulans & $52.74 \pm 2.62$ & $34.4 \pm 3.6 \mathrm{~b}$ & $68.9 \pm 3.4 \mathrm{~b}$ & $100 \pm 0.0 \mathrm{~b}$ \\
Myxomys whiteheadi & $42.42 \pm 2.13$ & $29.7 \pm 4.2 \mathrm{~b}$ & $72.6 \pm 6.9 \mathrm{~b}$ & $100 \pm 0.0 \mathrm{~b}$ \\
\hline
\end{tabular}

Note: Means in columns followed by the different letter are statistically different by Pairwise Mann-Whitney U test after Kruskal -Wallis test at the 0.05 level.

TABLE 3. VARIATIONS IN THE PERCENT (proportion) CONSUMED OF DIFFERENT BODY PARTS OF THE LARGE PREY SPECIES (when offered with three weight classes) BY THE BARN OWL

\begin{tabular}{|c|c|c|c|c|c|c|}
\hline \multirow{2}{*}{ Prey species } & \multirow{2}{*}{$\begin{array}{l}\text { Weight class } \\
\text { (g) }\end{array}$} & \multirow{2}{*}{$\begin{array}{c}\text { Mean weight } \\
(\mathrm{g}) \pm \mathrm{SE}^{*}\end{array}$} & \multicolumn{4}{|c|}{$\%$, Proportion of prey consumed \pm SE } \\
\hline & & & Entire-prey & Half body & Head alone & Dismembered prey \\
\hline \multirow[t]{3}{*}{$\begin{array}{l}\text { Rattus rattus } \\
\text { diardii }\end{array}$} & $\begin{array}{l}\text { Small } \\
(50-100)\end{array}$ & $95 \pm 1.51$ & $57.05 \pm 3.15 \mathrm{Aa}$ & $18.67 \pm 2.25 \mathrm{Bb}$ & $8.82 \pm 1.72 \mathrm{Bc}$ & $16.90 \pm 4.24 \mathrm{Bb}$ \\
\hline & $\begin{array}{l}\text { Medium } \\
101-150)\end{array}$ & $112 \pm 0.22$ & $11.14 \pm 1.92 \mathrm{Bb}$ & $34.75 \pm 2.22 \mathrm{Aa}$ & $32.66 \pm 3.99 \mathrm{Aa}$ & $19.15 \pm 1.42 \mathrm{Bb}$ \\
\hline & $\begin{array}{l}\text { Large } \\
(151-285)\end{array}$ & $245 \pm 1.11$ & $0.00 \pm 0.00 \mathrm{Cc}$ & $21.84 \pm 1.74 \mathrm{Bb}$ & $31.45 \pm 2.85 \mathrm{Ab}$ & $45.28 \pm 2.71 \mathrm{Aa}$ \\
\hline
\end{tabular}

Note: *Means followed by the different upper case letter within column or different lower case letter within row are statistically different by Pairwise Mann-Whitney U test after Scheirer-Ray-Hare test, $P=0.05$. 
TABLE 4. VARIATIONS IN THE PERCENT (proportion) CONSUMED OF DIFFERENT BODY PARTS OF THE SMALL PREY SPECIES (when offered with two weight classes) BY THE BARN OWL

\begin{tabular}{|c|c|c|c|c|c|c|}
\hline \multirow{2}{*}{ Prey species** } & \multirow{2}{*}{$\begin{array}{l}\text { Weight class } \\
\text { (g) }\end{array}$} & \multirow{2}{*}{$\begin{array}{l}\text { Mean weight } \\
\quad(\mathrm{g}) \pm \mathrm{SE}^{*}\end{array}$} & \multicolumn{3}{|c|}{$\%$, Proportion of prey consumed \pm SE } & \multirow[b]{2}{*}{ Dismembered prey } \\
\hline & & & Entire-prey & Half body & Head alone & \\
\hline \multirow[t]{4}{*}{ Rattus exulans } & Small & & & & & \\
\hline & $(20-50)$ & $37.50 \pm 1.31 \mathrm{~ns}$ & $82.05 \pm 2.95 a$ & $8.28 \pm 1.11 b$ & $7.08 \pm 1.29 b$ & $2.30 \pm 1.16 \mathrm{c}$ \\
\hline & Large & & & & & \\
\hline & $(51-80)$ & $63.27 \pm 2.25 \mathrm{~ns}$ & $74.64 \pm 2.51 \mathrm{a}$ & $25.74 \pm 4.16 b$ & $2.52 \pm 1.29 c$ & $0.95 \pm 0.73 c$ \\
\hline \multirow{3}{*}{$\begin{array}{l}\text { Maxomys } \\
\text { whiteheadi }\end{array}$} & Small & & & & & \\
\hline & $(20-50)$ & $35.00 \pm 1.74 \mathrm{~ns}$ & $73.27 \pm 6.66 a$ & $6.54 \pm 3.22 \mathrm{bc}$ & $12.39 \pm 3.24 b$ & $0.65 \pm 0.65 c$ \\
\hline & Large & $5357+248 \mathrm{nc}$ & $8293+449$ & $1337+294 \mathrm{~h}$ & $481+206 c$ & $094+066 c$ \\
\hline
\end{tabular}

Note: * Means in the same rows followed by the different letter are statistically different by Pairwise Mann-Whitney U test after ScheirerRay-Hare test (NPAR two-way ANOVA) test at the 0.05 level. ns (not significant) within column of two weight class.

** Each species was tested separately.

of breeding activity was increased screeching by the males, which begun intense marked territorial behaviour especially during our visits.

There was a consistent change of behaviour and foraging activity among breeding pairs approximately 19-21 days before actual egg laying. Occasionally, trespassing females were driven off with furious harsh screeches. Dominant females show defensive behaviour or pair calling with continuous screeching sound before the breeding season starts, especially when the 'food uploading' is initiated. Notably, the first sign of breeding initiation was the numerous castings and droppings in the nest box. The number of prey uptake showed an increase of 5\%-8\% than a month before. Foraging was normally engaged by males before the females laid their egg. The pairing was recorded at 2.5 months after the owls were first introduced to one another. Owls have their clutch size determined at the oviposition of the first egg of the clutch. Clutch size might be determined no later than a few days before the laying of the first egg. Female barn owls may use the pre-laying period to determine the clutch size using cues such as male food deliveries (a proxy for male quality). The record showed that laying season started in February and continued into April, June and September. Taylor (1994) stated that barn owls in Malaysia has three main breeding season; i) January-February, ii) July-September and ii) October-December compared to their continental counterparts with one or two seasons only. Besides that, Marti $(1992 ; 1994)$ reported that the owls rarely produce a second brood to replace failed first clutches but can produce a large clutch in a single brood.

Incubation period and eggs hatched. Female barn owls develop special brood patch called 'plumage' (pinkish colour) - an area of bare, featherless skin on the underside in preparation for incubation and brooding. During the 32 days of laying observed, there were five egg laying sessions recorded with an average of $6.2 \pm 0.5$ clutches size per female. Marti (1994) has described the barn owl (Tyto alba) as having a higher biotic potential and more flexible reproduction than most other owls and ecologically similar birds. Breeding pairs started regular visits to the nest boxes and prepare the bedding with their regurgitated pellets which described the evidence of a breeding season associated with increased weekly prey uptake (Durant et al., 2010). Each female laid a single egg every one to three days to a total of four to eight eggs. At this stage, the females still foraged for food before the hatching period. Rotating the eggs and changing their position is the normal behaviour of females. Within 29-32 days, the eggs hatched and from then on, the females seldom or never leave the nest, except when disturbed.

Rotating eggs is believed to help mitigate the effects of temperature fluctuations in the nest box. The rotation is a normal behaviour of a brooding hen or any other avian species. In addition, variation in the productivity of barn owls (Tyto alba) has been linked to fluctuations in prey abundance which proves the influence of changes in habitat quality within breeding seasons on the daily survival of broods (Taylor, 1994; Martin, 1998; Martin et al., 2010). In a similar study, Wiemeyer (1987) used the captive eastern screech - owls to see their reproduction in captivity. The results showed that average clutch size across the first clutches was 4.63 eggs, 3.21 eggs hatched per attempt, and 3.03 young fledged per attempt. The two breeding pairs in this study reproduced twice a year and was in agreement with Lenton (1984), Schulz and Yasuda (1985) i.e. owls often produce two and sometimes more broods per year. However, clutch size did not differ significantly among years or among nest sites in natural habitat (Colvin, 1984; Marti, 1990). In this finding, the unfertilised eggs were normally covered 
with dirt and isolated from the clutch of eggs cared by the female. With the high level of addled eggs recorded $(74 \%)$ the breeding-captive programme was considered to be far from success. Notably, Wiemeyer (1987) found that infertility and embryo deaths were the major causes of egg failure of the captive eastern screech-owls (Otus asio).

The two breeding pairs (parents) reproduced twice a year with the first clutches of eight and six eggs respectively, followed by six and seven for the second clutch correspondingly (Figure 1). The hatching rate for the owl designated with the code AT01 was $0 \%$ and $83 \%$. Later, shells were merely pushed into the corner of the nest box or buried in the accumulated pellets debris. While for the owl designated with the code JJ01, the hatchability percentage were $67 \%$ and $43 \%$ for both clutches.
Addled eggs ( $0 \%$ hatched) were recorded in the clutch of AT01 when the mother stopped incubating the eggs; most likely due to the frequent interruptions from regular inspection at Day 1, 3 and 7. Thus, un-hatched eggs usually remain in the nest until they were broken by the movements of the parent, young or buried in the accumulated pellets debris. In two cases, infertile eggs were not found in the nest box after the fledgling had flown. Visits were drastically reduced to twice a week for visual and video recordings. Subsequently, replacement for second clutch attempts happened at 44 days later. In-breeding case (designated with the code HT01) was recorded for the first generation from the parental pair code JJ01. For the completed cycle, JJ01 was capable of reproducing a second clutch after four months. In addition, the HT01 (first

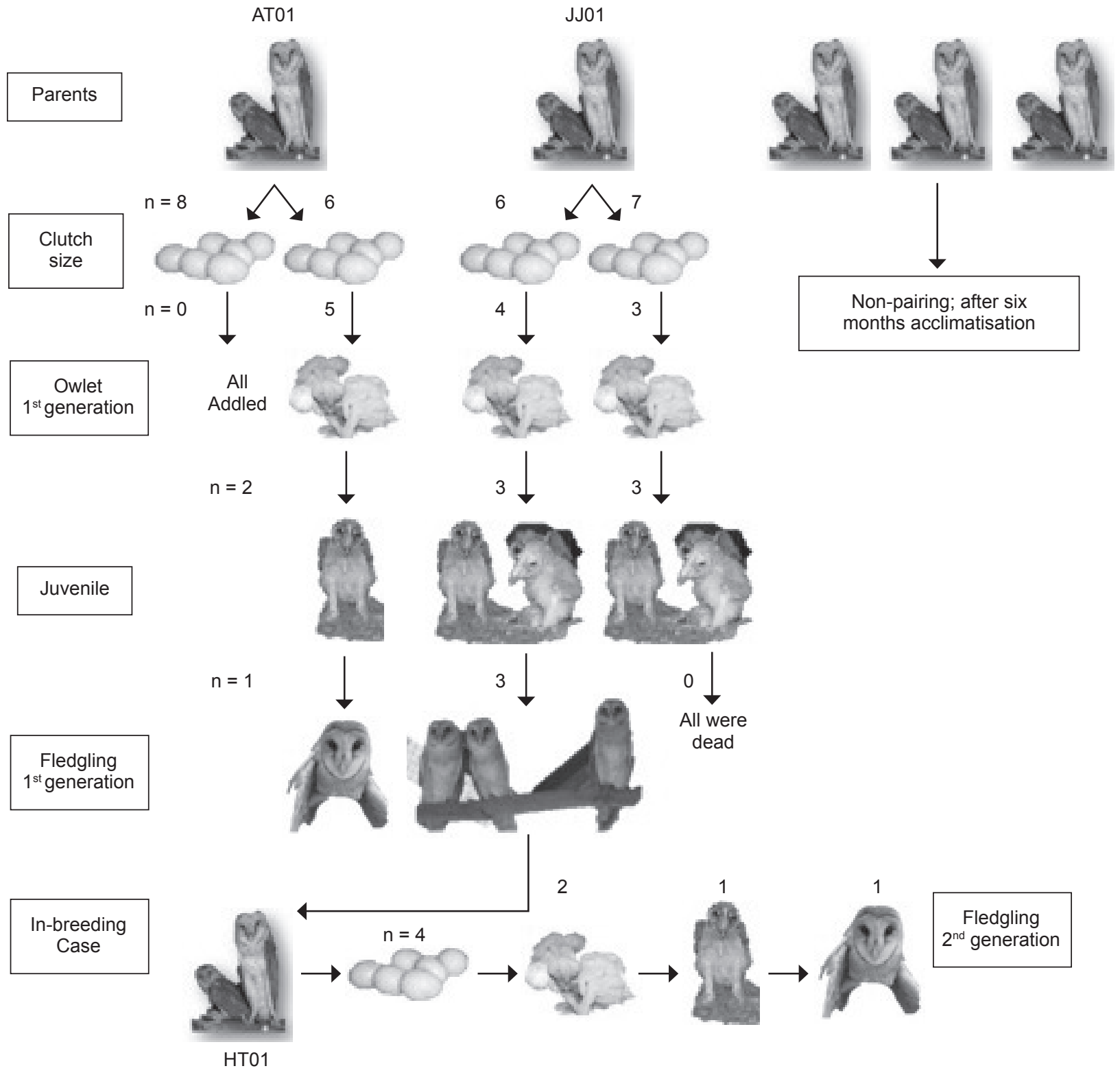

Figure 1. The ancestry of reproduction success from three parents of owl in captivity. 
generation) started laying eggs at 8.4 month aged with a clutch size of four and only $50 \%$ of the eggs hatched approximately 30 days later which produced $50 \%$ fledglings.

Post-hatching behaviour and family interaction in the nest box. During the feeding days, there were 150 feedings noted or an average of 8.3 feedings per night (12 hr), with an observed maximum of 13 feedings per night. The prey uptakes were drastically increased to double and almost triple compared to during incubation period when the pairs were busy feeding their chicks. Feeding time by the female seems to rely on the number of chicks and the size of prey delivered by the male. Feeding to last an average of 5 to $10 \mathrm{~min}$ interspersed with resting or grooming for a time interval of 6 to $46 \mathrm{~min}$. Male brought home additional preys which the females stocked up. Fresh preys were consumed up to Day 3 (depending on the size of prey) and may run up to more than five days. Sometime four to five preys were deposited in a nest box at any one time. The owlet needed little attention and can feed itself on the food stored at the nest by its parents.

Occasionally, the mother grabbed a headless, dismembered rat and later engorged the headless body, reaching out into the innards to feed the owlets. Females were preoccupied with their chicks and continued to stay with her brood after feeding. However after the breeding period was over, the adults would usually leave the nest as soon as after feeding and some grooming. The main call of the young after the first few days is the snore, which has a variety of functions. The owlets apparently become accustomed to the hunting times of their parents, and snored as a food call before the beginning of the evening activity. Some of owlets show a unique snoring towards their parents (Bunn and Warbutorn, 1977), with calm or noises with wings raised to stimulate the parents drive to forage for the young.

Fledging was $75 \%$ for the first clutch of parent code JJ01, 50\% HT01, followed by $34 \%$ for second clutch of AT01 and 0\% second clutch of JJ01. For JJ01, the second clutch (seven eggs) was recorded in June, produced $50 \%$ owlets and $0 \%$ fledged. In one instance, the oldest chick was killed by the parent and the regurgitated pellet holding the skull was found on the ground. This situation was in agreement with Lee (1998) who reported that cases of cannibalism and chick mortality still happen despite the availability of ample food resource. A week later the remaining two owlets died at two months old evidently from starving. During this period, it was observed that the pairs were under considerable stress as evidenced from the unexplained behaviour of dropping all preys caught from high up.
Reponses of juveniles towards prey. Owlets, particularly the oldest with a prey, if approached by another, immediately covered the food with its wings. Begging-display of owlets as they saw their parents approaching with prey was normal in our occasional visits. Significantly, in this display, the wings were supinated to show the flecking white undersides. In a somewhat similar threat display, their wings were pronated to show the upperside and were held rigid. Owlets under parenting care shows that the owlets gradually teach themselves to catch prey while still being supported by their parents.

From this finding, owlets start hunting large prey at 5-6 months old which probably has some association with the early breeding of the first generation (HT01) in captivity at 8.4 months old as suggested by Bunn et al. (1982) and Lenton (1984). In total, nine juveniles $(64.3 \%)$ were recorded from five breeding counts but only five of these fledged (55\%). Young fledglings took 29-32 days to leave the nest box. The fledglings were capable of hunting at 4-5 weeks old. There was relatively little overlap in the species and weight of prey captured by males and females, suggesting that food-niche partitioning between the sexes may exist, possibly to reduce food competition between the sexes (Pande and Dahanukar, 2012). Most preys were headless since the male killed the prey by decapitating and consumed the head first before delivering the remaining carcass to the nest box. Moreover, male owls had a significantly higher frequency of visits with prey than females.

In training aviary, the owlets were fed by the author. At 5 to 6 weeks old, most fledglings are only capable of hunting small sized prey (i.e. R. exulans, $M$. whiteheadi and small individuals of the R. r. diardii - $50 \mathrm{~g}$ ) and tended to avoid medium and large sized rat. They gradually buid up the ability of hunting medium size R. r. diardii at the age of 2.33.1 months old and large size (dismembered and decapitated) at $5.1-6.3$ months old. At 5 - 6 weeks old, owlets were recorded to regurgitate pellets after $10 \mathrm{hr}$ of consuming the prey.

\section{CONCLUSION}

The study implies that barn owls preferred small prey and followed with different species, feeding on certain body parts (i.e. head and dismembered bodily remains) in the case of large prey size or species in keeping with efficient feeding and energetics requirement. This baseline feeding data and preference for prey size and weight class were especially useful when the owls which were bred in captivity were later released in new areas in Sabah and Borneo. In particular, this is the first study of its kind involving fecundity parameters 
such as clutch size, brood size, rate of growth of nestlings and fledging success in captive barn owls in Sabah. The incubation period lasts for 29-32 days, during which time the female seldom leaves the nest (with little grooming); with the males not taking part in the incubation. One case of cannibalism was recorded. Breeding was considered moderately successful under ad libitum feeding since live preys were continuously supplied to the owls. Subsequently, we believe that the breeding-captive programme or acclimatisation of barn owls in an aviary should be around three months period or only once breeding case per pair. However, in this study, the crucial part was the owlet stage (only $36 \%$ survived). It is anticipated that the role of barn owls in regulating rat activities can be significant in the future with this preliminary study. The next phase of the study should look into the foraging and reproductive success of barn owls released in the oil palm fields.

\section{ACKNOWLEDGEMENT}

We would like to thank Felda Global Ventures Research and Development (FGV R\&D) for granting the whole projects and the Wildlife Department, Department of Veterinary Services of Sabah, Department of Veterinary Services, and Department of Wildlife and National Parks (PERHILITAN) of Pahang for the permission to bring in barn owl from Peninsular to Sabah. Our sincere thanks to the staff of Crop Protection Department, FGV R\&D at Sahabat, Lahad Datu, Sabah and Tun Razak, Jengka, Pahang for assistance rendered in this study. Many thanks to Syed Salim Syed Ali, the Executive Vice President of FGV R\&D and Agri Service cluster, and Dr Sharifah Shahrul Rabiah Syed Alwee, Chief Executive Officer of FGV (R\&D), for their comments and approval to publish this article.

\section{REFERENCES}

BONTZORLOS, V A; PERIS, S J; VLACHOS, C G and BAKALOUDIS, D E (2005). The diet of barn owl in the agricultural landscape of central Greece. Folia Zoology, 54(1-2): 99-110.

BUNN, D S and WARBUTORN, A B (1977). Observations on breeding barn owls. Brit. Birds, 70: 246-256.

BUNN, D S; WARBUTORN, A B and WILSON, R D S (1982). The Barn Owl. Buteo Books, Vermillion, S D.

CALVIN, D (2003). Choosing and Using Statistics: A Biologist's Guide. Department of Biology, University of York, Blackwell Science. 248 pp.
CASTRO, S A and JAKSIĆ, F M (1995). Great horned and barn owl prey differentially according to the age/ size of a rodent in north central Chile. J. Raptor Research, 29: 245-249.

CAVALLI, M; BALADRON, A V; ISACCH, J P; MARTINEZ, G and BO, M S (2014). Prey selection and food habits of breeding burrowing owls (Athene cunicularia) in natural and modified habitats of Argentine pampas. Emu, 114: 184-188.

CIK MOHD RIZUAN, Z A and NOOR HISHAM, $H$ (2015). Composition and distribution of small rodents in FGV's oil palm regions in Sabah and Sarawak. Book of Abstracts PIPOC 2015. 6-8 October 2015. KLCC, Kuala Lumpur, Malaysia. p. 117.

COLVIN, B A (1984). Barn Owl Foraging Behaviour and Secondary Poisoning Hazard from Rodenticide Use on Farms. Ph.D dissertation. Bowling Green State University. Bowling Green, Ohio, USA. 326 pp.

DETIENNE, D C; HOLT, D; SEIDENSTICKER, M T and PITZ, T (2008). Diet of snowy owls wintering in west-central Montana, with comparisons to other North American studies. J. Raptor Research, 42(3): 172-179.

DURANT, J M; GENDNER, J P and HANDRICH, Y (2010). Behavioural and body mass changes before egg laying in the barn owl: cues for clutch size determination? J. Ornithology, 151(1): 11-17.

GLIWICZ, J (2008). Body size relationships between avian predators and their rodent prey in a NorthAmerican sagebrush community. Acta Ornithologica, 43(2): 151-158.

GRIFFITH, D (1980). Foraging cost and relative prey size. The American Naturalist, 116: 743-752

FLIKWEERT, M; PRINS, T G; DE FREITAS, J A and NIJMAN, V (2007). Spatial variation in the diet of the barn owl Tyto alba in the Caribbean. Ardea, 95(1): 75-82.

FOLEY, C; LAU, W T; LAU, J S and TAN, K H (2013). Field study breeding barred eagle owl Bubo sumatranus sumatranus in Johor, Malaysia. Birding ASIA, 19: 34-37.

FRANCIS, C M (2008). A Field Guide to the Mammals of South-east Asia. New Holland Publishers (UK) Ltd. 392 pp.

GUBANYI, J A; CASE, R $\mathrm{M}$ and WINGFIELD, $G$ (1992). Diet and nesting success of barn owls breeding in western Nebraska. American Midland Naturalist, 127: 224-232. 
HAFIDZI, M N; NAIM, M and AKBAR, Z (2003). Feeding ecology of barn owl Tyto alba in rice fields. J. Malaysian Applied Biology, 32(2): 41-46.

HAFIDZI, M N; NAIM, M and AKBAR, Z (2007). Influence of wet and dry season on barn owl propagation and its relation on rat damage. Pertanika J. Tropical Agricultural Science, 30(1): 45-50.

HASBER, S; HAFIDZI M N; NOOR HISHAM, H; DZOLKHIFLI, O; AZHAR, K; CHE SALMAH, MD R; ABU HASSAN, A and MOHD RIZUAN, Z A (2014). Sub-lethal effects of the anticoagulant rodenticides bromadiolone and chlorophacinone on breeding performances of the barn owl (Tyto alba) in oil palm plantations. Slovak Raptor J., 8(2): 113-122.

HEYWOOD, M R and PAVEY, C R (2002). Relative importance of plague rodents and dasyurids as prey of barn owls in central Australia. Wildlife Research, 29: 203-207.

ILLE, R (1991). Preference of prey size and profitability in barn owls Tyto alba guttata. Behaviour, 116: 180-189.

JACOB, J (1974). Quantitative measurement of food selection; a modification of the forage ratio and Ivlev's electivity index. Oceologica, 14: 413-417.

KARELL, P; LEHTOSALO, N; PIETIAINEN, H and BROMMER, J E (2010). Ural owl predation on field voles and bank voles by size, sex and reproductive state. Annales Zoologici Fennici, 47(2): 90-98.

KHALEGHIZADEH, A; ARBABI, A; NOORI, G; JAVIDKAR, M and SHAHRIARI, A (2009). Diet of wintering long-eared owl Asio otus in Zabol, Southeastern Iran. Ardea., 97(4): 631-633.

LEE, C H (1998). Barn owl - development and food utilization. J. Tropical Agriculture and Food Science, 26(2): 151-157.

LENTON, G M (1984). The feeding and breeding ecology of barn owls Tyto alba in Peninsular Malaysia. Ibis, 126: 551-575.

LITTLES, C J; WILLIFORD, D; SKORUPPA, M K; WOODIN, M C and HICKMAN, G C (2007). Diet of Western burrowing owls wintering in Southern Texas. J. Raptor Research, 39: 156-159.

MARTI, C D (1990). Same-nest polygyny in the barn owl. Condor, 92: 261-263.

MARTI, C D (1992). Barn owl (Tyto alba). Birds of North America, No. 1. (Poole, A and F Gill, eds.). The
Academy of Natural Sciences. Philadelphia, PA and The American Ornithologists> Union, Washington, DC, USA.

MARTI, C D (1994). Barn owl reproduction: patterns and variation near the limit of the species distribution. Condor, 96: 468-484.

MARTI, C D (2009). A compariosn of method for estimating prey biomass of barn owls. J. Raptor Research, 43(1): 61-63.

MARTI, C D (2010). Dietary trends of barn owls in an agricultural ecosystem in Northern Utah. The Wilson. J. Ornithology, 122(1): 60-67.

MARTI, C D and HOGUE, J G (1979). Selection of prey by size in screech owls. The Auk, 96: 319-327.

MARTIN, T E (1998). Are microhabitat preferences of coexisting species under selection and adaptive? Ecology, 79: 656-670.

MARTIN, J M; BRANCH, L C; RAID, R N and BEYELERS, S C (2010). Temporal instability of agricultural habitat reduces reproductive success of barn owls (Tyto alba). The Auk, 127(4): 909-916.

MUHAMMAD, M U H; MIRZA A B; MUHAMMAD MUSHTAQ, U H; HABIB, A M and MUHAMMAD $S$ (2007). Nesting and diet of the barn owl (Tyto alba) in Pakistan. J. Raptor Research, 41(2): 122-129.

NAIM, M; HAFIDZI, M N; KASSIM, A and ABU, J (2011). Comparison of the breeding performance of the barn owl Tyto alba javanica under chemical and bio based rodenticide baiting in immature oil palms in Malaysia. Dynamic Biochemistry, Process Biotechnology and Molecular Biology @ Global Science Books, 5(2): 5-11.

PANDE, S; PAWASHE, A; MAHAJAN, M N; JOGLEKAR, C and MAHABAL, A (2007). Effect of food and habitat on breeding success in spotted owlets (Athene brama) nesting in villages and rural landscapes in India. J. Raptor Research, 41(1): 26-34.

PANDE, S and DAHANUKAR, N (2012). Reversed sexual dimorphism and differential prey delivery in barn owls (Tyto alba). J. Raptor Research, 46(2): 184189.

PAYNE, J and FRANCIS, C M (1985). A Field Guide to the Mammals of Borneo. The Sabah Society. Reprinted 2007. 332 pp.

PUAN, C L; GOLDIZEN, A W; HAFIDZI, M N and BAXTER, G S (2011). Absence of differential 
predation on rats by Malaysian barn owls in oil palm plantations. J. Raptor Research, 45(1): 71-78.

SCHULZ, T A and YASUDA, D (1985). Ecology and management of the common barn owl (Tyto alba) in the California Central Valley. Proc. Raptor Res. Found. Symp. Sacramento, CA.

SMAL, CM (1990). Research on the use of barn owls Tyto alba for biological control of rats in oil palm plantations. Proc. of the 1989 International Palm Oil Development Conference - Agriculture. PORIM, Bangi. p. 342-356.

SUNDE, P; FORSOM, H M; MOHAMMAD NAFI SOLAIMAN AL-SABI, and OVERSKAUG, K (2007). Selective predation of tawny owls (Strix aluco) on yellow necked mice (Apodemus flavicollis) and bank voles (Myodes glareolus). Annales Zoologici Fennici., 49(5-6): 321-330.

TAYLOR, I (1994). Barns Owls; Predator-prey Relationship and Conservation. Cambridge University Press. p. 304.
TAYLOR, I R (2009). How owls select their prey: a study of barn owls Tyto alba and their small mammal prey. Ardea, 97(4): 635-644.

TORES, M; MOTRO, Y; MOTRO, U and YOMTOV, Y (2005). The barn owl - a selective opportunist predator. Israel J. Zoology, 51: 349-360.

TREJO, A and GUTHMANN, N (2003). Owl selection on size and sex classes of rodents: activity and microhabitat use of prey. J. Mammalogy, 84: 652658.

TREJO, A and LAMBERTUCCI, S (2007). Feeding habits of barn owls along a vegetative gradient in Northern Patagonia. J. Raptor Research, 41(4): 277287.

VANITHA, V and KANAKASABAI, R (2009). Prey selection by the barn owl Tyto alba (Scopoli, 1769) in captivity. J. Threated Taxa., 1(7): 361-365.

WIEMEYER, S M (1987). Propagation of captive eastern screech-owls. J. Raptor Research, 21(2): 49-56. 